\title{
Should Economics Play a Role in Copyright Law and Policy?
}

Pamela Samuelson*

3

6

10

13

20

1. INTRODUCTION

2. WHY HAS ECONOMICS HAD SO LITTLE IMPACT ON COPYRIGHT SO FAR?

3. WHAT EFFECT WILL ELDRED V. ASHCROFT HAVE ON THE FUTURE OF ECONOMICS IN COPYRIGHT?

4. WHEN MIGHT ECONOMICS BE USEFUL?

5. CONCLUSION 
HeinOnline -- 1 U. Ottawa L. \& Tech. J. 2 2003-2004 


\title{
Should Economics Play a Role in Copyright Law and Policy?
}

\author{
Pamela Samuelson
}

\section{INTRODUCTION}

THE PRINCIPAL JUSTIFICATION for intellectual property (IP) laws in the AngloAmerican tradition is economic." Without a grant of exclusive rights, innovators would have too little incentive to invest in socially beneficial innovations for this simple reason: developing the first embodiment of an innovation generally requires a very substantial investment; subsequent copies are generally far less costly to make, and are often trivially cheap and easy. ${ }^{2}$ If creators cannot prevent others from selling products embodying their innovations-which copyists can offer at a lower price if able to free-ride on the innovator's first copy costs-innovators will not be able to recoup their research and development (R\&D) costs and justify further investments in innovations. ${ }^{3}$ Although the non-excludable, nonrival character of intellectual creations resembles public goods, ${ }^{4}$ it is socially desirable for private actors, rather than the government, to make the investments to overcome this public goods problem. ${ }^{5}$ Intellectual property rights are an ingenious device for addressing this problem: the government grants rights to qualifying innovators, and the rights provide incentives to individuals to invest in innovation because the rights granted provide assurance that innovators can recoup their R\&D costs if their intellectual creations prove to be valued by the

1. See e.g. Paul Goldstein, Copyright's Highway: From Gutenberg to the Celestial Jukebox (New York: Hill and Wang, 1996); Mark A. Lemley, "The Economics of Improvement in Intellectual Property Law" (1997) 75 Tex. L. Rev. 989 at 1074-76.

2. See e.g. Wendy J.Gordon, "Asymmetric Market Failure and Prisoner's Dilemma in Intellectual Property" (1992) 17 U. Dayton L. Rev. 853.

3. See e.g. Pamela Samuelson et al., "A Manifesto Concerning the Legal Protection of Computer Programs" (1994) 94 Colum. L. Rev. 2308 (making this sort of economic argument for legal protection against cloning of computer program innovations).

4. See e.g. Wendy J. Gordon, "Fair Use as Market Failure: A. Structural and Economic Analysis of the Betamax Case and its Predecessors" (1982) 82 Colum. L. Rev. 1600 at 1610-11 [Gordon, "Fair Use"].

5. ibid. at 1611-12. 
public. ${ }^{6}$ Original works of authorship are particularly vulnerable to marketdestructive copying, which is why few question the economic wisdom of a copyright regime. ${ }^{7}$

Intellectual property would, for this reason, seem to be "a natural field for economic analysis of law." It would, hence, be logical for economic analysis to have considerable influence in shaping copyright and other intellectual property laws. ${ }^{9}$ Yet, as compared with other fields of economic regulation, particularly antitrust law, economics has very little influence thus far in the intellectual property law and policymaking process. This essay considers why this might be so in the field of copyright law and whether economics might become more influential in this field of law and policy in the future.

The lack of influence is not attributable to inattention from the scholarly community. Law and economics scholars have produced a substantial and growing literature that analyzes many aspects of copyright law. ${ }^{10}$ Among the copyright rules that are widely viewed as economically sound are: the idea/expression distinction (that is, copyright protects only an author's expression, not her ideas), ${ }^{11}$ the independent creation defense, ${ }^{12}$ the derivative work right (that is, the right to control adaptations of the work, such as a motion picture version of a novel), ${ }^{13}$ the separation of the ownership of a copy of a work from ownership of the copyright in it, ${ }^{14}$ the ability of authors to assign "slices" of their exclusive rights, ${ }^{15}$ limits on the duration of copyright, ${ }^{16}$ and the work made for hire rule (which treats employers as the "author" of works by employees performed within the scope

6. See e.g. Jerome H. Reichman, "Electronic information Tools--The Outer Edge of World Intellectual Property Law" (1993) 24 int'l Rev. Ind. Prop \& C'right L. 446.

7. See e.g. William M. Landes \& Richard A. Posner, "An Economic Analysis of Copyright Law" (1989) $18 \mathrm{~J}$. Legal Stud. 325 at 333-44 (presenting a formal model of copyright). But see Stephen Breyer, "The Uneasy Case for Copyright: A Study of Copyright in Books, Photocopies, and Computer Programs" (1970) 84 Haw. L. Rev. 281 [Breyer, "Uneasy Case"] (questioning the economic need for copyright). See also Barry W. Tyerman. "The Economic Rationale for Copyright Protection for Published Books: A Reply to Professor Breyer" (1971) 18 UCLA L. Rev. 1100; Stephen Breyer, "Copyright: A Rejoinder" (1972) 20 UCLA L. Rev. 75.

8. Landes \& Posner, supra note 7 at 325.

9. See e.g. Richard A. Posner, Economic Analysis of Law, 5th ed. (New York: Aspen Law \& Business, 1998) (surveying economic analysis of many bodies of law).

10. Among the classic works are: Breyer, "Uneasy Case", supra note 7; Gordon, "Fair Use", supra note 4; Gillian K. Hadfield, "The Economics of Copyright: An Historical Perspective" (1992) 38 Copyright L. Symposium 1; Robert M. Hurt \& Robert M. Schumann, "The Economic Rationale of Copyright" (1966) 56 Am. Econ. Rev. 421; Landes \& Posner, supra note 7; Arnold Plant, "The Economic Aspects of Copyright in Books" (1934) 1 Economica 167. These and other important articles on copyright can be found in Wendy J. Gordon \& Richard Watt, Economics of Copyright: Developments in Research and Analysis (Northampton, MA: E. Elgar, 2003); Ruth Towse \& Rudi Holzhauer, The Economics of Intellectual Property, vol. 1 (Northampton, MA: E. Elgar, 2002) at Parts II-V. Other important, but more recent, work is cited throughout this article.

11. 17 U.S.C. \& 102(b) (2001) <http://frwebgate.access.gpo.gov/cgi-bin/getdoc.cgi?dbname=browse_usc\& docid=Cite:+17USC102>. See e.g. Landes \& Posner, supra note 7 at $347-53$.

12. ibid. at 345-47.

13. 17 U.S.C. ₹ 106(2) (2001) <http://frwebgate.access.gpo.gov/cgi-bin/getdoc.coi?dbname=browse_wsc\& docid=Cite:+17USC106>. See e.g. Landes \& Posner, supra note 7 at 354-55.

14. 17 U.S.C. $\$ 202$ (2001) <http://frwebgate.access.gpo.gov/cgibin'getdoc.cgi?dbname=browse_usc\&docid=Cite: +17 USC202>.

15. 17 U.S.C. $\S 201$ (d) (2001)<http://frwebgate.access. gpo.gov/cgibin/getdoc.cgi?dbname=browse_usc\&docid=cite: +17 USC201>.

16. 17 U.S.C. $\S \S 302-304$ (2001) <http://wmw.access.gpo.gov/uscode/title 17/chapter 3 .html $>$. See infra notes $51-55$ and accompanying text for economic arguments in favor of limits on the duration of copyrights. 
of employment). ${ }^{17}$ The economics of copyright collectives and of compulsory licensing has also garnered scholarly attention. ${ }^{18}$ Cultural economics, a subfield of economics, has studied the market for art and cultural products, such as opera and theatre, and offered insights about policies needed to induce investment in these cultural forms. ${ }^{19}$ One bold work considers whether economics is friend or foe of copyright, ${ }^{20}$ but rare is the work that attempts to analyze the economics of copyright as a whole.

Among the most studied subjects has been the economics of the fair use doctrine of US copyright law. ${ }^{21}$ Economists and economically minded legal scholars often view uses of copyrighted works as fair if high transaction costs or other factors have impeded the effective establishment of a market for clearing rights, ${ }^{22}$ Particularly influential has been Wendy Gordon's analysis of the fair use issues in the Sony Betamax case. Gordon argued that use of Betamax machines to tape broadcast television programs for later viewing should be fair because the costs of negotiating rights clearances would greatly exceed fees collectable for this kind of socially beneficial use. ${ }^{23}$ Economics is especially useful in providing guidance on this copyright issue because the economic effects of a challenged use are almost always of central importance in judging whether the use will be deemed non-infringing as a fair use. ${ }^{24}$

Economists and economically minded legal scholars have questioned or criticized certain copyright rules as economically unsound. For example, it is unnecessary for personal letters and diaries to automatically qualify for copyright protection, given that these works would be created without the economic incentives of copyright. ${ }^{25}$ Special exemptions from copyright liability for certain events organized by agricultural cooperatives and veterans' groups seem to be

17. 17 U.S.C. \& 201 (b) (2001) <http;/frwebgate.access.gpo.gov/cgibin/getdoc.cgi?dbname=browse_usc\&docid=Cite:+17USC201>. See e.g. 1.T. Hardy, "An Economic Understanding of Copyright Lav's Work-Made-For-Hire Doctrine" (1988) 12 Colum.V.L.A. J. L. \& Arts 181.

18. See e.g. Stanley M. Besen. Willard G. Manning \& Bridger M. Mitchell, "Copyright Liability for Cable Television: Compuisory Licenseing and the Coase Theorem" (1978) 21 J.L. \& Econ. 67; Stanley M. Besen, Sheila N. Kirby \& Steven C. Salop, "An Economic Analysís of Copyright Collectives" (1992) 78 Va. L. Rev. 383; Robert P. Merges, "Contracting Into Liability Rules: Intellectual Property Rights and Collective Rights Organizations" (1996) 84 Cal. L. Rev. 1293.

19. See e.g. Joni M. Cherbo \& Margaret Jane Wyszomirski, eds., The Public Life of the Arts in America (New Brunswick, NJ: Rutgers University Press, 2000); Ruth Towse, ed. A Handbook on Cultural Economics (Northampton, MA: E. Elgar, 2003).

20. See Richard Watt, Copyright and Economic Theory: Friends or Foes? (Northampton, MA: E. Elgar, 2000).

21. See e.g. Timothy J. Brennan, "Harper \& Row y. The Nation, Inc.: Copyrightability and Fair Use" (1986) 33 J. of Copyright Soc'y U.S.A. 368; William T. Fisher III, "Reconstructing the Fair Use Doctrine" (1988) 101 Harv. L. Rev. 1659; Gordon, "Fair Use", supra note 4; S. J. Liebowitz, "Copying and Indirect Appropriability: Photocopying of Journals" (1985) $93 \mathrm{~J}$. Pol. Econ. 945; Landes \& Posner, supra note 7 at 357-61; Robert P. Merges, "Are You Making Fun of Me? Notes on Market Failure and the Parody Defense of Copyright" (1993) 21 A.I.P.L.A.Q.J. 305; Alfred C. Yen, "When Authors Won't Sell: Parody, Fair Use, and Efficiency in Copyright Law" (1991) 62 U. Colo. L. Rev. 79. See also Lisa N. Takeyama, "Welfare Implications of Unauthorized Reproduction of intellectual Property in the Presence of Demand Network Externalities" (1994) 42 J. Ind. Econ. 155.

22. See e.g. Gordon, "Fair Use", supra note 4 at 1652-57.

23. ibjd. at 1602-22.

24. The effect of a challenged use on the market, or potential market, for a copyrighted work is one of the principal criteria for judging whether a use is fair. See 17 U.S.C. \& 107 (2001) <http://frwebgate.access.gpo.gov/cgi-bim/getdoc.cgi?dbname=browse_usc\&docid=cite: +17 USC 107>.

25. See e.g. William M. Landes, "Copyright Protection of Letters, Diaries, and Other Unpublished Works: An Economic Approach" (1992) $21 \mathrm{~J}$. Legal Stud. 79. 
the product of special interest lobbying, rather than rigorous economic analysis. ${ }^{26}$ Extension of the duration of copyrights in existing works ${ }^{27}$ and so-called "restoration" of foreign copyrights that had long been in the public domain for failure to comply with US formalities ${ }^{28}$ (for instance, putting copyright notices on published copies of the work) are also economically questionable, ${ }^{29}$

As interesting and provocative as the literature on the economics of copyright is, even its most ardent fans would have to admit that economics has rarely played a significant role in the copyright law and policymaking process. Section 2 will consider various reasons why economics has not been more influential in copyright up until now. Section 3 will discuss the economics of extending the terms of existing copyrights and the Supreme Court's decision in the Eidred v. Ashcroft case. ${ }^{30}$ Although an initial reading of the Supreme Court's decision might suggest a dim future influence of economics on copyright law, Section 3 explains why this interpretation of the Eldred decision is incorrect. Section 4 will discuss particular venues in which economics would be most useful in advancing the copyright law and policymaking process. Legislators should (and occasionally do) seek independent economic expertise when considering copyright and related intellectual property proposals. Courts may find economic analysis a useful input to sound decision-making, especially in cases involving new technology issues unanticipated when legislatures adopted copyright laws. Section 5 will consider some reasons why copyright professionals might resist the incursion of economics into the copyright policy process, and why economics should nonetheless play a more important role in copyright policymaking in the future.

\section{WHY HAS ECONOMICS HAD SO LITTLE IMPACT ON COPYRIGHT SO FAR?}

ONE SALIENT FACTOR EXPLAINING why economic analysis has had so little impact on copyright law and policy is a lack of economic expertise in the relevant policy making community. Many copyright professionals have backgrounds in fields other than economics and are more inclined to embrace a romantic conception about art and literature and the people and firms who create and commercialize copyrighted works. This tendency disinclines them to look to economics for guid-

26. See 17 U.S.C. $\$ \$ 110(6), 110(10)(2001)<h t t p: / / f r w e b g a t e . a c c e s s . g p o . g o v / c g i-$ bin/getdoc.cgi?db hame=browse_usc\&docid=Cite:+17uSC110s.

27. See Somy Bono Copyright Term Extension Act, Pub. L. No. 105-298, 112 Stat. 2827 (1998;, codified at 17 U.5.C. $\$\{302(a), 302$ (c) (2001) <http://fiwebgate.access.gpo.gov/cgi-bin/getdoc.cgi?dbname:=browse usc\&docjd=Cite: +17 USC 302>, discussed infra notes $47-72$ and accompanying text.

28. 17 U.S.C. § 104A (2001) <http:/frwebgate.access.gpo.gov/cgibir/getdoc.cgi?dbname=browse usc\&dacid $=$ Cite: +17 USC104A>. See e.g. Edward Lee, "The Public's Domain: Evolution of Legal Restraints on the Government's Power to Control Public Access Through Secrecy or Intellectual Property" 55 Hastings L.J. [forthcoming in 2004] [discussing economic and constitutional problems with "restoration" of these copyrights).

29. See e.g. Richard A. Epstein, "The Dubious Constitutionality of the Copyright Term Extension Act" (2002) 36 Loy. L.A. L. Rev. 123; Dennis S. Karjala, "Judicial Review of Copyright Term Extension Legislation" (2002) 36 Loy. LA. L. Rev. 199.

30. Eldred v. Ashcroft, 537 U.S. 186, <http://www.supremecourtus.gov/opinions/02pdf/01-618.pdf>, 123 5.Ct. 769 (2003). 
ance about how the law should be crafted. ${ }^{31}$ Unlike the US Department of Justice Antitrust Division, the Federal Trade Commission and the Federal Communications Commission (FCC), for example, all of whom regularly participate in policy making as to other economic regulations, the US Copyright Office (as well as its patent and trademark counterpart) has no in-house economic experts who might contribute insights about economic effects of various policy proposals ${ }^{32}$

For path-dependent historical reasons, copyright and other intellectual property policy matters in the US have generally been considered by subcommittees of the House and Senate Judiciary Committees, rather than by Commerce Committees, from which economic regulations often emerge. These subcommittees have relied heavily on industry witnesses when considering copyright and other intellectual property-related legislation. Copyright industry groups, in fact, often write the laws that the legislature enacts. ${ }^{33}$

A revolving door enables copyright experts to move from the legislature or legislative committee staff positions to law firms representing major copyright firms to industry associations to government agencies responsible for framing copyright law and policy. ${ }^{34}$ This contributes to insularity in copyright policy analysis.

The US is not alone in its systematic, if perhaps unconscious, exclusion of or inattention to economic analysis in the copyright policy-making process. Nations whose legal rules are grounded in the natural right of authors in their works, ${ }^{35}$ especially those that affirm that authors have moral rights in their works, have less reason to perceive economics as a useful input in the policymaking process than the U.S., which at least historically conceptualized copyright in utititarian terms.

Although the tight nexus between the copyright industry and the policymaking community is the main reason economics has thus far had so little influence on copyright law and policy, it is not the only factor at work. An impediment to influence is that economists who study copyright issues often speak in a lariguage inaccessible to policymakers and copyright professionals. Few copyright

31. See e.g. Peter Jaszi, "Toward a Theory of Copyright: The Metamorphoses of 'Authorship'" (1991) Duke L.J. 455 (discussing the romantic conception of copyright). See also Breyer, "Uneasy Case", supra note 7 at 284-91 (discussing non-economic justifications for copyright).

32. A decade ago, I recommended that government offices charged with responsibilities for intellectual property policy should hire staff economists. See Pamela Samuelson, "Will the Copyright Office Be Obsolete in the Twenty-First Century?" (1994) 13 Cardozo Arts \& Ent. L.J. 55.

33. See e.g. Jessica Litman, Digital Copyright (Amherst, NY: Prometheus Books, 2001); William F. Patry, "Copyright and the Legislative Process: A Personal Perspective" (1996) 14 Cardozo Arts \& Ent. L.J. 139 at 141 .

34. The President of the Association of American Publishers, for example, is Pat Schroeder, formerly a Congresswoman. The recently retired head of the Business Software Alliance, Emery Simon, was with the US Trade Representative Office where he worked on intellectual property issues before joining BSA. Bruce Lehman who served as head of the Patent \& Trademark Office during the Clinton Administration had been a legislative staffer in Congress before becoming a lawyer who represented copyright industry groups. Shira Perimutter, formerly with the US Copyright Office, is now a Vice President and Associate General Counsel for Intellectual Property at AOL Time Warner.

35. France and Germany are among the countries that protect authors' rights on this basis. See e.g. Goldstein, supra note 1 at 168-69; Alain Strowel, "Droit d'auteur and Copyright: Between History and Nature" in Brad Sherman \& Alain Strowel, eds., Of Authors and Origins: Essays on Copyright Law (New York: Oxford University Press, 1994) 235 
professionals are able, for example, to penetrate the mathematical expressions that often pervade the academic economic literature. If economists wish for their work to inform the copyright policy process, they will have to learn to translate their insights into a more vernacular form. They may also need to publish policyrelevant work in venues where policymakers would be likely to read it.

Cultural differences are also a factor. Lawyers and policymakers view some problems that deeply engage economists (e.g., the optimal duration of a patent or of copyright protection for computer software $\left.{ }^{36}\right)$ as a waste of time. Other issues of interest to economists (e.g., network externalities) may have policy implications that are not readily apparent to copyright professionals. ${ }^{37} \mathrm{~A}$ legal and policy audience may find incomplete an economic analysis whose policy implications are not spelled out. If economists want their work to inform the copyright policymaking process, they will have to invest the extra time necessary to articulate the policy implications that flow from their analyses.

The standard economic practice of articulating simplifying assumptions before constructing an economic analysis does not mesh well with the mindset of lawyers and policymakers either. If the whole edifice of an analysis depends on assumptions $A, B, C, D$ and $E$ being true and at least one of them is questionable, lawyers and other policy analysts may be inclined to discredit the analysis as a house of cards.

Influencing copyright law and policy will also require economists to give this field somewhat greater attention. Economic research on intellectual property issues has tended to focus on subjects for which funding from government or foundation grants is available. Until quite recently, grant-makers rarely supported research on copyright issues. Far more economic research has been done on patent issues, mainly because of their significance for the predominant industrial economy of the 19th and 20th centuries, but also because more funding has historically been available to study the economics of patents. The emergence of an information-based economy in the late 20th century has attracted the attention of economists and economically-informed lawyers to exploring the economics of copyright. ${ }^{38}$

Also an impediment to influence, is the plain fact that economics will not always yield an unimpeachable policy prescription for copyright issues. This is partly due to the complex intricacies of the many industries that rely upon or intersect with copyright law. Since copyright law has many provisions of general applicability that affect a wide range of industries-from book publishing to

36. See e.9. Richard Gilbert \& Carl Shapiro, "Optimal Fatent Length and Breadth" (1990) 21 RAND J. Econ. 106 (arguing for a thin scope and long term of protection for patents); Feter \$. Menell, "Tailoring Legal Protection for Computer Software" (1989) 39 Stan. L. Rev. 1329 (arguing for short duration for legal protection for software); Samuelson et al., supra note 3 at 2423 (arguing for a short duration of legal protection against cloning of computer program behavior and other industrial design features of programs).

37. See e.g. Michael L. Katz \& Carl J. Shapiro, "Network Externalities, Competition and Compatibility" (1985) 75 Amer. Econ. Rev. 424 (discussing economics of network externalities). An important contribution to the legal literature on network effects is Mark A. Lemley \& David F. McGowan, "Legal Implications of Network Economic Effects" (1998) 86 Cal. L. Rev. 479 (drawing out several possible legal implications of network externalities)

38. See e.g. Joseph Farrell, "Standardization and Intellectual Property" (1989) 30 Jurimetrics J. 35: Wendy J. Gordon, "On Owning Information" (1992) 78 Va. L. Rev. 149; Lemley \& McGowan, supra note 37; Menell, supra note 36; J.H. Reichman, "Legal Hybrids Between the Patent and Copyright Paradigms" (1994) 94 Colum. L. Rev. 2432; Samuelson et al., supra note 3. See also sources infra note 127. 
architecture to computer software to theatrical performances, just to name a few-it may be very difficult, if not impossible, to assess with any precision the economic effects likely to flow from adoption of particular copyright rules, let alone the economics of the copyright regime as a whole. ${ }^{39}$

It is to be expected, moreover, that on many issues, economists will differ in their analyses of the same issue. In A\&M Records, Inc. v. Napster, Inc., for example, economic experts offered widely varying analyses of the effects of peer to peer file sharing on the market for digital music. ${ }^{40}$ Some economists considered file sharing to be benign or beneficial, while others asserted it was harmful to the market for sound recordings. ${ }^{41}$ Policymakers will understandably be reluctant to put much weight on economic expertise if equally qualified experts offer irreconcilably conflicting analyses of the same phenomenon.

Another barrier to influence is the understandable reluctance of copyright lawyers and policy professionals to acknowledge the public choice problems presented by the current copyright law and policy-making process. ${ }^{42}$ These problems are well-documented in the scholarly literature. ${ }^{43}$ Major copyright firms are well-organized and well-funded. They typically have a common interest in getting stronger legal rules from the legislature. Hence, it may be a sound investment for them to lobby to achieve the concentrated benefit a legislature can grant them. The public may ultimately have to pay higher costs if copyright lobbyists are successful, but these costs are diffused and distributed over a broad base of people and firms. Collective action problems make it difficult for parties that will be negatively affected by higher protection rules to organize effective resistance to copyright industry lobbying. This mix of concentrated benefits and distributed costs is likely to yield the best laws money can buy. The Copyright Term Extension Act (CTEA), ${ }^{44}$ the Digital Millennium Copyright Act (DMCA) anti-

39. See e.g. David McGowan, "Copyright Nonconsequentialism" (July 8, 2003) (emphasizing indeterminate relationship between copyright rules and desired outcomes) [unpublished, on file with author]; George Priest, "What Economists Can Tell Lawyers About intellectual Property: Comment on Cheung" (1986) 8 Research in Law and Economics 19 (questioning the usefulness of economic analysis in respect of intellectual property law because of inadequacies in empirical understanding of innovation).

40. 239 F.3d 1004 (9th Cir. 2002) at 1016-17, <http:/(www ca9.uscourts.gov/ca9/newopinions, nsf/ bA17BB3944F3170788256A230058515C/\$filer0016401.pdf?openelement> at 16 [Napster].

41. Plaintiffs' economic expert David Teece focused on the harmful effects on the plaintiffs' ability to offer competing digital music services. Bbid. at 1017. Defendants' expert argued that use of Napster for sampling purposes enhanced the willingness of users to buy recorded music. Wid. Plainttfs commissioned two empirical studies of the effects of peer to peer filesharing on sales of recorded music which concluded that among college students, purchases had declined because of Napster filesharing. Ibid. at 1016.

42. On public choice generally, see e.g. William N. Eskridge, Jr. "Implications of Public Choice Theory for Statutory interpretation" (1988) 74 Va. L. Rev. 275; Daniel A. Farber \& Philip P. Frickey, Law and Public Choice: A Critical introduction (Chicago: University of Chicago Press, 1991).

43. See e.g. Glynn S. Lunney, Jr., "The Death of Copyright: Digital Technology, Private Copying and the Digital Millennium Copyright Act" (2001) 87 Va. L. Rev. 813; Neil W. Netanel, "Locating Copyright Within the First Amendment Skein" (2001) 54 Stan. L. Rev. 1; Patry, supra note 33; Stewart E. Sterk, "Rhetoric and Reality in Copyright Law" (1996) 94 Mich. L. Rev. 1197.

44. See supra note 27. A Canadian legislative proposal to extend the term of copyrights in unpublished works was controversial. See James Adams "Estates' Rights in Canadian Copyright Re-examined" The Globe and Mail (23 September 2003) R2, <http://wmwtheglobeandmail.com/serviet/ArticleNews/TPStory/LAG/ 20030923/COPY23/TPEntertainment/TopStories>, James Adams "Bill's death opens diaries of Canadian notables" The Globe and Mail (15 Novernber 2003) R16, shttp://wmw.globeandmail.ca/servlet/ ArticleNews/TPStory/LAC/20031115/MONT15//?query=copyright>. 
circumvention provisions, ${ }^{45}$ and state "super-DMCA" laws ${ }^{46}$ are three widely recognized examples from the US experience.

\section{$\star$ \\ 3. WHAT EFFECT WILL ELDRED V. ASHCROFT HAVE ON THE FUTURE OF ECONOMICS IN COPYRIGHT?}

A STARK EXAMPLE OF THE BATTLE between economic and non-economic reasoning in the copyright law and policy process is evident in the Eldred v. Ashcroft case recently decided by the US Supreme Court. ${ }^{47}$ Eric Eldred, an online publisher of public domain works, challenged the CTEA, which extended copyright terms an additional twenty years, based on an economic theory of the Intellectual Property Clause of the U.S Constitution. ${ }^{48}$ Article I, $\S 8, \mathrm{Cl} .8$ gives Congress power "to promote the progress of Science and useful Arts, by securing to Authors and Inventors for limited times the exclusive Right in their respective Writings and Discoveries." Boiled down to its essence, Eldred's theory was that this clause prohibited Congress from granting exclusive rights to authors without the quid pro quo of a "progress-promoting" (i.e., authorship of a newly created original work) in return. ${ }^{49}$ Stated more colloquially, Congress violated the Constitution by extending the term of existing copyrights for an additional twenty years because the public got nothing in return for that grant. The CTEA was purely a windfall to existing copyright owners. Such a quid pro nihilo, Eldred argued, failed to satisfy constitutional standards. ${ }^{50}$

Seventeen economists-including five Nobel Prize winners-signed a friend-of-the-court brief to the US Supreme Court in support of Eldred's challenge to the CTEA. ${ }^{51}$ The brief made the obvious point that the CTEA could not incent the creation of works already in existence. ${ }^{52}$ It went on to consider the deadweight loss that a longer term of above-cost pricing would bring, as well as the substantial transactions costs the CTEA imposes on subsequent users. ${ }^{53}$ Tracking down copyright owners and negotiating with them is costly, even if the owners do not insist on payments for reproducing or distributing copies of their

45. Pub. L. No. 105-304, 112 Stat. 2860 (1998), codified as amended at 17 U.S.C. 51201 <http:/frwebgate.acces5.gpo.gov/cgibin/getdoc.cgi?dbname=browse_usc\&docid=Cite: +17USC 1201>.

46. See eg. Alex Breeding "What Are the Implications of the New Super-DMCA Laws?" TechRepublic (16 July 2003), <http://techrepublic.com.com/5100-6314-5054407.html>. A status report on enactment of state super-DMCA laws can be found at 〈http://www.freedom-to-tinker.com/superdmca.html〉.

47. Eldred, supra note 30. Justices Stevens and Breyer dissented in separate opinions, the former offering an alternative historical and constitutional analysis, and the latter mainly focusing on the economic effects of the CTEA at 790-801, <http://supct.law.cornell.edu/supct/htm//01-618.20.htmls (Stevens dissent) and 801-15, <http://supct.law cornell.edu/supctihtm//01-618.ZD1.html> (Breyer dissent).

48. See Eldred, supra note 30 (Brief for Petitioners, <http://cyber.law harvard edu/openlaw/eldredvashcroft/supct/opening-brief.pdf> at 15-28). Eldred also argued that the CTEA violated the First Amendment at 34-48.

49. ibid. at 23 .

50. ibid.

51. See Eldred, supra note 30 (Brief of George A. Akerloff et al., <http://cyber.law.harvard.edulopenlaw/ eldredvashcroft/supct/amici/economists.odfs). Akerloff, Kenneth Arrow, James Buchanan, Ronald Coase, and Milton Friedman were the Nobel Prize winning signatories of this brief. See Ibid., Appendix A.

52. ibid. at 8 .

53. Wid at 11-13. 
works. CTEA impedes public access to many works that are no longer commercially exploited, but that may still be of interest, as well as preventing the creation of many new derivative works. ${ }^{54}$ The economists' brief also pointed out that life of the author plus seventy years was virtually equivalent to the perpetual term of copyright that the Constitution forbids..$^{55}$

The Supreme Court rejected Eldred's challenge to the CTEA. Congress had a rational basis, the Court decided, for believing that CTEA would lead to more investments in distributing and preserving existing works. ${ }^{56}$ The Constitution gave to Congress the responsibility of crafting copyright legislation, and even if it exercised this power unwisely, the Court was reluctant to secondguess legislative decisions. ${ }^{57}$ Only Justice Breyer would have struck down the CTEA on an economic interpretation of the Constitution. ${ }^{58}$

The Eldred opinion is starkly different from many of the Court's rulings on economic regulations. Economic analysis is generally quite influential when the Supreme Court assesses economic regulations, especially among the more conservative members of the Court. ${ }^{59}$ Given how often the Court has emphasized the economic incentive rationale for the existence of copyright law, ${ }^{60}$ it is striking how little attention was paid to economics in Eldred. Justice Ginsburg, who authored the majority opinion, is not, of course, the most economically minded of the Justices. But the de-emphasis on economics in Eldred has other roots.

There is a deep rift within the Court about constitutional powers of Congress and about how much deference to give to legislation emanating from Congress. ${ }^{61}$ Eldred's lawyers drew upon several Supreme Court precedents interpreting the constitutional powers of Congress in a restrictive manner and establishing rigorous standards for judging the constitutionality of certain kinds of legislation. ${ }^{62}$ Further limitations on Congress' power under Article 1, $\S 8, \mathrm{cl} .8$ were, Eldred's lawyers argued, consistent with these recent precedents, ${ }^{63}$ as well as with the Court's prior rulings under the Intellectual Property clause. ${ }^{64}$ Eldred's

54. Ibid. at 12-14.

55. ibid. at 8 .

56. Eldred, supra note 30 at $781-82$.

57. Bid. at 783-84.

58. Ibid. at 801, Breyer, J., dissenting: "The economic effect of this 20-year extension-the longest blanket extension since the Nation's founding-is to make the copyright term not limited, but virtually perpetwal... And most importantiy, its practical effect is not to promote, but to inhibit the progress of 'Science' by which word the Framers meant learning or knowledge...."

59. See e.g. Eastman Kodak Co, v. Pmage Technical Services, Inc, et al., 504 U.S, 451 (1992), <http://supct.law.cornell,edu/supcthtm/90-1029.ZS.html>, 199 L. Ed. 2d 265; Jefferson Parish Hosp. Dist. No. 2 v. Hyde, 466 U.S. 2 (1984), 104 S. Ct. 1551.

60. See e.g. Mazer v. Stein, 347 U.S. 201, 219 (1954), 74 S. Ct. 460; Sony Corp. of Am. v. Universal City Studios, inc, 464 U.\$. 417, 429 (1984), 774 S. Ct. 774.

61. See e.g. United States v. Lopez, 514 U.S. 549 (1995), 115 S. Ct. 1624 [Lopez]; United States v. Morrison, 529 U.S. $598(2000), 120$ S. Ct. 1740 [Morrison]. In both decisions, Justices Breyer, Ginsburg, Souter and Stevens dissented from rulings that Congress lacked power under the Commerce Clause to enact legislation to regulate guns near schoois and gender-based crimes of violence. See e.g. Paul J. Heald \& Suzanna Sherry, "Implied Limits on the Legislative Power: The Intellectual Property Clause as an Absolute Constraint on Congress" (2000) U. III. L. Rev. 1119 (discussing numerous Supreme Court decisions restrictively interpreting Congress' power and considering their implications for various intellectual property provisions).

62. See Brief for Petitioners, supra nate 48 at 11-12 (invoking Lopez, (bid. and Morrison, (bid.).

63. Ibid.

64. ibid. at 12-13, 20-21. 
lawyers hoped the analogy to these other restrictive rulings would woo the more conservative members of the Court to further restrictions on Congress' constitutional powers in Eldred. Eldred's lawyers used a different strategy to persuade Justices Breyer and Stevens (who had dissented in the earlier challenges to Congress' power) to support Eldred's cause. ${ }^{65}$

There was, in short, a lot going on in the Eldred case that had nothing whatsoever to do with copyright law but a good deal to do with the Court's internal debate on the scope of Congress' powers under the Constitution. Other factors were also at play. Most significant was the indisputable fact that Congress had extended the term of existing copyrights numerous times before: in 1790, 1831, 1909, and 1976, as well as several other times leading up to enactment of the Copyright Act of $1976 .{ }^{66}$ Although Eldred's lawyers developed an elaborate chart to distinguish the CTEA from other extensions, ${ }^{67}$ this chart may have backfired because it underscored the frequency of these enactments. "To comprehend the scope of Congress' power [to extend terms of existing copyrights] under the Copyright Clause," said the Court, "a page of history is worth a volume of logic." 68

The Court was also understandably concerned about the implications of a ruling in Eldred's favour. If the CTEA was invalid, the retroactive term extensions in the Copyright Act of 1976 would almost certainly be challenged, and it was not immediately evident how the Court could find a principled basis for distinguishing this extension from the CTEA. ${ }^{\circ 9}$ Had the Court acceded to the heightened scrutiny for which Eldred argued, 70 it might have opened the floodgates of constitutional challenges to intellectual property legislation, not just to copyright rules. ${ }^{71}$ Finally, Eldred was willing to accept that life of the author plus seventy years was a "limited time" under the Constitution applied prospectively. ${ }^{72}$ In view of this, the Court thought that life plus seventy years must also be sufficiently limited applied retroactively.

Taking into account the range of explanatory factors, the Eldred decision may be less of a setback for a significant role for economic analysis in copyright

65. In view of Justice Breyer's earlier economic skepticism about copyright, see Breyer, supra note 7, Eldred's lawyers expected him to be skeptical of the CTEA on economic grounds and receptive to arguments based on the constitutional history of the Intellectual Property Clause indicating that the Framers embedded limits in it in order to guard against rent-seeking. See Brief for Petitioners, supra note 48, at 23-26. Eldred's lawyers thought Justice Stevens would be receptive to their arguments because his opinion in Sony Corp. of Am. v. Universal City Studios, Inc., supra note 60. Therein he emphasized copyright as a limited monopoly, the primary purpose of which was to promote public access to knowledge. "The monopoly privileges that Congress may authorize are neither unlimited nor primarily designed to provide a special private benefit. Rather, the limited grant is a means by which an important public purpose may be achieved. It is intended to motivate the creative activity of authors and inventors by the provision of a special reward, and to allow the public access to the products of their genius after the limited period of exclusive control has expired.")

66. Supra note 47 at $775-76$.

67. See Eldred, supra note 30 (Reply Brief for the Petitioners, < http://cyber.law. hanard.edu/openlaw/ eldredvashcroftsupct/final.pdf> Addendum at 1a (chart distinguishing CTEA from other extensions).

68. Supra note 47 at 778 (quoting New York Trust Co. v. Eisner, 256 U.5. 345 at 349 (1921)),

69. ibid. at 790 .

70. Brief for Petitioner, supra note 48 at $39-47$; Eldred, supra note 47 at $788-90$.

71. See e.g., Pamela Samuelson, "The Constitutional Law of Intellectual Property after Eldred v. Ashcroft" (2003) 50 J. Copyright Soc'y U.S.A 547 at 556.

72. Supra note 47 at 775 . 
law and policy than a cursory glance might suggest. The Court was not willing to interpret the Constitution as mandating economically sound results, but this does not mean that the Court believes that copyright law and policy should be uninformed by economic analysis. The next section will consider several contexts in which economic analysis has been, and is likely to be, a useful input into the policymaking process for copyright and related forms of intellectual property law.

\section{WHEN MIGHT ECONOMICS BE USEFUL?}

WHEN LEGISLATURES CONSIDER PROPOSALS to add a new subject matter to copyright, or to adopt new copyright-like forms of legal protection, they should (and occasionally do), seek input from impartial economic experts about whether such legislation is necessary to address a market failure that is deterring socially optimal investments in particular classes of innovations or information resources. Economic expertise, for example, had some influence in the US when the National Commission on New Technological Uses of Copyrighted Works (CONTU), made economic as well as doctrinal arguments urging that copyright law be used to protect computer programs. ${ }^{73}$ The European Union, too, relied on economic analysis in crafting appropriate copyright rules for computer programs. ${ }^{74}$ Owing in substantial part to the decisions of the US and the EU to protect programs by copyright, this rule became an international standard in 1994, after member states of the World Trade Organization (WTO) acceded to the Agreement on Trade-Related Aspects of Intellectual Property Rights (TRIPS), which required copyright protection for programs. ${ }^{75}$

The US Congress has a more mixed record in relying on economic aralysis when considering sui generis (of its own kind), forms of legal protection for other innovations. It relied heavily on economic arguments when adopting in

73. See Final Report of the National Commission on New Technological Uses of Copyrighted Works luly 31 , 1978, <http://digital-law-online.info/CONTU/PDF/index.htmls (Washington D.E.: Library of Congress, 1979). The CONTU analysis focused on the economics of developing individual programs, but did not consider the appropriate scope of copyright protection for computer programs or vexing issues such as the interoperability and decompilation issues discussed infra notes 101-120 and accompanying text.

74. See EC, Council Directive 91/250 on the Legal Protection of Computer Programs. <http://europa.eu.int/smartapi/cgi/sga doc?smartapilcelexapilprod!CELEXnumdoc\&ig=en\&mumdoc $=31991 \mathrm{LO} 250$ \&model=guichett> [1991] O.J.L. 122/42 at articie 6. Lof this Directive permits decompilation of computer program code for purposes of achieving interoperability among programs) [Software Directive]. See e.g. Pamela Samuelson, "Comparing U.S. and E.C. Copyright Protection For Computer Programs: Are They More Different Than They Seem?" (1994) 13 J. L. \& Com. 279 at $287-88$ (discussing the concerns of the European Commission's competition directorate about the software directive that influenced the rule in favor of decompilation for interoperability purposes).

75. See Trade-Related Aspects of Intellectual Property Rights, Annex $1 \mathrm{C}$ of the Marrakesh Agreement Establishing the World Trade Organization, signed in Marrakesh, Morocco on 15 April 1994, at article 10(1) <http://www.wto.org/english/tratop_e/trips_e/trips_e.htm> [TRIPS]. 
1984, a new law to protect original layouts of circuits in semiconductor chips. ${ }^{76}$ However, it adopted a copyright-like form of legal protection for vessel hulls and other boat parts in 1998, without serious economic evidence or expertise to support it ${ }^{77}$ Yet, economic analysis has had some cautionary influence on Congress in the debate about whether to adopt an equivalent sui generis right in the data in databases such as the EU adopted in 1996.78

The European Commission asserted a market failure rationale to justify the issuance of a Directive to member states of the EU requiring them to adopt a sui generis form of intellectual property protection for controlling extraction and reuse of data in databases. ${ }^{79}$ Without such a law, the theory went, there would be too few incentives to invest in database development. ${ }^{80}$ The new law confers, on those who invest substantial resources in database development, fifteen years of exclusive rights to control extraction and reuse of all or substantial parts of the databases (renewable for additional fifteen year terms so long as substantial investments continue). ${ }^{81}$

Although the Commission invoked an economic rationale for this law, it neglected to provide any empirical evidence of market failure or rigorous economic analysis of the regime proposed to cure the perceived failure. Had the Commission been more rigorous in its use of economics, the European Parliament might have realized there was less of a need for this sui generis law than the Commission posited and might have adopted a somewhat narrower form of legal protection for data in databases. ${ }^{22}$

Economic input should also be sought when copyright laws are amended. Had the US Congress, for example, sought impartial advice from economists about the effects of copyright term extension before enacting the CTEA, it is conceivable that economic arguments against it would have persuaded some

76. See Semiconductor Chip Protection Act of 1984, Pub. L. No. 98-620, 98 Stat. 3347, codified as amended at 17 U.S.C. \& 901 (1984)<http:/www4, law,cornell.edu/uscode/17/90\% html >. See e.g. Prepared Testimony of F. Thomas Dunlap, Jr., Corporate Counsel and Secretary of Intel Corp., Hearings Before the Subcommittee on Courts, Civil kiberties, and the Administration of Justice of the House Committee on the Judiciary, on H.R. 1028, 98th Cong., 1st Sess. (8/3/8.3) explaining the industry's need for this legislation; Prepared Statement of Sen. Charles M. Mathias, Jr., House Hearings, supra, at 3; "[Chip] innovators are being ripped off by onshore and offshore 'chip pirates' who, for a fraction of the developer's cost, can now legally appropriate and use these chip designs as their own." Of particular concern was the loss to Japanese industry of a substantial share of the market for random access memory chips to Japanese competitors whose superior quality control made their chips very competitive. See Stephen P. Kasch, "The Semiconductor Chip Protection Act: Past, Present, and Future" (1993) 7 High Tech. L.J. 71 at 79.

77. See Vessel Hull Design Protection Act, Pub. L. No. 105-304 tit. V, 112 Stat. 2905 (1998), codified at 17 U.S.C. $\$ 51301-1332$ (1998) <http://www4 law.cornell.edu/uscode/17/ch 13.html>. Had this law been subjected to impartial economic analysis, it is difficult to believe Congress would have passed it.

78. See e.g. Jerome Reichman \& Paul F. Uhlir, "Database Protection at the Crossroads: Recent Developments and Their Impact on Science and Technology", (1999) 14 Berkeley Tech. L.J. 793 (discussing the evolution of legislative proposals).

79. See EC, European Parliament and Council Directive 96/9/EC of 11 March 1996 an the Legal Protection of Databases, <http://europa.eu.int/smartapi/cgi/sga_doc?smartapilcelexapilprod!CELEXnumdoc\&lg=en\& numdoc $=31996$ LOOO9\&model=guichett> [1996] O.J. L77/20. [EU Database Directive]. See, e.g. Jerome Reichman \& Pamela Samuelson, "Intellectual Property Rights in Data?" (1997) 50 Vand. L. Rev. 51 at $80-97$ [Reichman \& Samuelson\} (providing a history of the justification for and evolution of this Directive].

80. EU Database Directive, ibid. recitals 1-12.

81. Ibid. arts. 7,10

82. See e.g. Reichman \& Samuelson, supra note 79 at $113-36$ (criticizing the EU sui generis regime because of its potential harmful effects on competition and irnovation as well as for science). 
in Congress to oppose it..$^{83}$ Economic analysis might also have been useful in assessing the anti-circumvention provisions of the DMCA, which have been heavily criticized as overbroad and anti-competitive. ${ }^{84}$

Copyright rules are also sometimes promulgated in the context of agency rule-making. Economic analysis should be a useful input to decisionmaking in this venue as well. For example, the Copyright Office is required to make determinations about claims for allocation of compulsory license revenues to particular copyright owners. ${ }^{85}$ Economic analysis would be helpful in making such assessments. Proposals for new compulsory licenses or revisions to existing compulsory licenses should, likewise, be scrutinized for economic soundness. ${ }^{86}$ The US Copyright Office has been given power to conduct rule-makings every three years to consider whether to exempt certain classes of works or uses of works from anti-circumvention rules. ${ }^{87}$ This should be a forum in which the Office might be educated about the economic effects of broad anti-circumvention rules.

Once rules have been legislated or issued by an appropriate agency, economics may sometimes have a useful role to play, and sometimes not, in how the law is interpreted thereafter. If a legislature has adopted an open-ended rule (e.g., that copyright protects an author's expression, not her ideas or methods), economic analysis may be a useful tool in interpreting the law in an economically sound way. However, if the legislature has precisely crafted certain rules that prove to be economically harmful, it may be more appropriate to invoke economic analysis to support proposed amendments to the law than in interpreting the rules in litigation.

An instructive example of the pros and cons of economic analysis in the interpretation of operi-ended copyright rules can be found in the US judicial experience interpreting copyright law as applied to computer programs. ${ }^{88}$ Whelan Associates v. Jaslow Dental Labs., Inc. was the first American appellate decision to consider whether the "structure, sequence, and organization" ("SSO") of computer programs could be protected by copyright law. ${ }^{89}$ Whelan relied upon both doctrinal and economic grounds in ruling that SSO was copyright-protectable. The doctrinal analysis relied on this syllogism: computer programs are considered to be literary works under US copyright law, and since the structure, sequence, and organization of literary works are, generally, protected by copyright law, the structure, sequence, and organization of programs should be protected by copyright law as well..$^{90}$

83. See e.g. Brief of Akerlof, supra note 51; Karjala, supra note 29.

84. See e.g. Pamela Samualson \& Suzanne Scotchmer, "The Law and Economics of Reverse Engineering" (2002) 111Yale L.J. 1575 at 1630-49 (critical of anti-circumvention regulations).

85. See e.g. 17 U.S.C. \$\$ 1003-1007 <http://www4.law.cornell.edu/uscode/17/ch 10schC.htmls.

86. See e.g. Neil W. Netanel, "Impose a Noncommercial Use Levy to Allow Free Peer-to-Peer File Sharing" (2003) 17 Harv. J. L. \& Tech. 1.

87. 17 U.S.C. \& 1201(a)(1)(c), shttp://www4.law.cornell.edu/uscode/17/1201.htmil>. See Memorandum from Mary Beth Peters to James Billington (27 Octaber, 20003) regarding Recommendations of RM 2002-4, Rulemaking on Exemptions from Prohibition on Circumvention of Copyright Protection Systems For Access Control Technologies. <http://www.copyright.gov/1201/docs/registers-recommendation.pdf>.

88. The subsequent paragraphs on Whelan, Altai and Sega v. Accolade derive from Pamela Samuelson, "Economic and Constitutional Influences on Copyright Law in the United States" (2001) 23 Eur. I. P. Rev. 409.

89. Whelan Associates inc. v. Jasiow Dental Laboratory, inc., 797 F.2d 1222 (3rd Cir. 1986). [Whelan].

90. ibid. at $1239-40$. 
Complementing this doctrinal analysis was an economic argument that focused on the need for software developers to have sufficient protection to recoup development costs and on the locus of value in computer programs:

By far the larger portion of the expense and difficulty in creating computer programs is attributable to the development of the structure and logic of the program, and to debugging, documentation and maintenance, rather than to the coding. See Frank, Critical issues in Software 22 (1983) (only $20 \%$ of the cost of program development goes into coding); Zelkowitz, Perspective on Software Engineering, 10 Computing Surveys 197-216 (June, 1978). See also InfoWorld, Nov. 11, 1985 at 13 '"the 'look and feel' of a computer software product often involves much more creativity and often is of greater commercial value than the program code which implements the product..."). The evidence in this case is that Ms. Whelan spent a tremendous amount of time studying Jaslow Labs, organizing the modules and subroutines for the Dentalab program, and working out the data arrangements, and a comparatively small amount of time actually coding the Dentalab program. ${ }^{91}$

The Third Circuit took seriously a friend-of-the-court brief submitted by a software industry organization. The brief argued that if copyright protection did not extend to the SSO of a program, the software industry would be jeopardized because the law would provide too little protection to induce an optimal level of investment in development of computer programs. ${ }^{92}$ The Third Circuit directly responded to this plea: "The rule proposed here, which allows copyright protection beyond the literal computer code, would provide the proper incentive for programmers by protecting their most valuable efforts, while not giving them a stranglehold over the development of new computer devices that accomplish the same end." $" 93$

Between 1986 and 1992, the Whelan decision was influential in subsequent US cases, both in its doctrinal and economic reasoning ${ }^{94}$ The first decision that challenged Whelan's hegemony was Computer Associates v. Altai, Inc. in 1992.95 On one important point, the Second Circuit Court of Appeals agreed with Whelan: the structure, sequence and organization of a program could, in an appropriate case, be protected by copyright law.96 Unlike Whelan, which regarded program structure as exempt from infringement only when there was essentially no other way to structure the program, ${ }^{97}$ the court in Altai reasoned that similarities in the structure of two programs might, however, be due to functional constraints such as the need to develop a program that would interoperate with another program, efficiency considerations, or use of the same standard programming techniques, none of which was protected by copyright law. ${ }^{98}$

91. ibid. at 1231 .

92. See Whelan Associates, inc. v. Jaslow Dental Laboratory, Inc. (Civ. A. No. 85-1358) (1986) (Brief Amicus Curiae of ADAPSO, The Computer Software and Services Industry Association, Inc.).

93. Whelan, supra note 89 at 1237.

94. See e.g. Johnson Controls, Inc. v. Phoenix Control Systems, inc., 886 F.2d 1173 (9th Cir. 1989); Lotus Development Corp.v. Paperback Software Intern., 740 F. Supp. 37 (D. Mass. 1990).

95. Computer Associates international v. Altai, Inc., 982 F.2d 693 (2nd Cir. 1992) [Aita].

96. Ibid. at 702-3.

97. Whelan, supra note 89 at 1240.

98. Altai, supra note 95 at 708-11. 
The court in Altai directed that these and other unprotectable elements of programs be "filtered out" before infringement analysis began" to ensure compliance with section 102(b) of the US copyright statute which states that "[i]n no case shall copyright protection for an original work of authorship extend to any idea, procedure, process, system, method of operation, concept, principle, or discovery, regardless of the form in which it is described, explained, illustrated, or embodied in such work." 100 The court ultimately ruled that some structural similarities in Altai were attributable to the fact that both Computer Associates (CA) and Altai were developing programs to interoperate with the same three $I B M$ operating system programs, and other structural similarities were to be expected in programs of that kind. ${ }^{101}$ Hence, it affirmed the lower court's finding of noninfringement.

As in Whelan, CA and its amici predicted dire economic consequences for the software industry if courts did not provide strong protection to program structure. However, the Second Circuit took a different view:

[The Supreme Court's decision in] Feist teaches that substantial effort alone cannot confer copyright status on an otherwise uncopyrightable work... [D]espite the fact that significant labor and expense often goes into computer program flow-charting and debugging, that process does not always result in inherently protectable expression. Thus, Feist implicitly undercuts the Whelan rationale, "which allow[ed] copyright protection beyond the literal computer code...[in order to] provide the proper incentive for programmers by protecting their most valuable efforts...." [citation omitted]. We note that Whelan was decided prior to Feist when the "sweat of the brow" doctrine still had vitality. In view of the Supreme Court's recent holding, however, we must reject the legal basis of $C A^{\prime}$ 's disincentive argument. ${ }^{102}$

The Second Circuit went on to say:

[W] are unpersuaded that the test we approve today will lead to the dire consequences for the computer program industry that plaintiff and some amici predict. To the contrary, serious students of the industry have been highly critical of the sweeping scope of copyright protection engendered by the Whelan rule, in that it "enables first comers to 'lock up' basic programming techniques as implemented in programs to perform particular tasks." 103

The Second Circuit warned that if courts heeded purely economic arguments for broadening the scope of copyright protection for computer programs, this would impair the integrity of copyright law:

99. Ibid, at 707 .

100. 17 U.S.C. $\$ 102\langle$ b) $(2001)<h t t p: / /$ frwebgate.access.gpo.gov/cgi-bin/getdoc.cgi?dbname=browse_usc\& docid=Cite: +17 USC102>.

101. Altai, supra note 95 at $708-711$.

102. libid. at 711-12.

103. Ibid. at 712 (citation omitted). 
While incentive based arguments in favor of broad copyright protection are perhaps attractive from a pure policy perspective,... ultimately, they have a corrosive effect on certain fundamental tenets of copyright doctrine. If the test we have outlined results in narrowing the scope of protection, as we expect it will, that result flows from applying, in accordance with Congressional intent, long-standing principles of capyright law to computer programs. $^{104}$

The Second Circuit pointed out that patent protection might be a more suitable way to protecting some program innovations than copyright. ${ }^{105}$ If copyright proved to be too "thin" to provide proper incentives to program developers, this was a matter for Congress, not the courts, to consider. ${ }^{106}$

Altai holds that copyright protection is unavailable to elements of programs necessary for interoperation with other programs (that is, program interfaces). ${ }^{107}$ Judged purely in terms of the creativity and judgment required to design them, program interfaces might initially seem to be "original" enough to be protectable expression as a matter of copyright law. ${ }^{108}$ However, once developed, program interfaces unquestionably constrain the design choices of subsequent programmers seeking to develop software capable of successfully interacting with an existing program. ${ }^{109}$

The competition policy significance of copyright protection for interfaces was recognized in Europe in part because the Competition Policy Directorate of the European Commission had taken action against IBM arising from its practice of changing interfaces in a manner that had exclusionary impacts on European developers of computer peripherals. ${ }^{110}$ If European software developers were going to be able to compete with US software in the world market, these developers would need to be able to use interface information from American programs. The EC Competition Policy Directorate intervened in negotiations surrounding the drafting of a directive on the legal protection for computer software that resulted in these economic considerations being brought to bear on the scope of copyright protection for software in Europe. ${ }^{111}$ The US and EU consensus on limiting copyright to enable interoperability influenced other nations as well. "172

104. Bhid

105. Ibid.

106. Ibid.

107. lbid. at 707-11.

108. See e.g. Arthur R. Miller, "Copyright Protection for Computer Programs, Databases, and ComputerGenerated Works: is Anything New Since CONTU?" (1993) 106 Harv. L. Rev. 977 (arguing that interfaces should be protectable by copyright).

109. Aitai, supra note 95 at 710 .

110. See e.g. Alan K. Palmer \& Thomas C. Vinje, "The EC Directive on The Legal Protection Of Computer Software: New Law Governing Software Development" (1992) 2 Duke J. Comp. \& Int'l L. 65.

111. Bbid. at $71-78$.

112. See e.g. Jonathan Band \& Masanobu Katoh, interfaces on Trial: intellectual Property And interoperability in The Global Software industry (Boulder, Co: Westview Press, 1995) at 271-97. 
Sega Enterprises, Ltd. v. Accolade, Inc. ${ }^{113}$ addressed a related interoperability issue as to whether programmers could lawfully decompile or disassemble other firms' programs in order to get access to information needed to develop an interoperable program. This was a dicey issue for copyright law because the decompilation and disassembly process inevitably requires the making of a number of copies of the target program. ${ }^{114}$ Such copies arguably run afoul of the exclusive right that copyright law confers on authors to control the reproduction of their works in copies. ${ }^{115}$ Yet unless copyright law recognized at least a limited right to decompile or disassemble programs, the decision not to protect interface information would be significantly undermined. ${ }^{116}$

Accolade relied on the fair use defense of US copyright law in responding to Sega's charge of infringement. ${ }^{117}$ Courts consider four factors in determining whether a use is fair: the purpose of the defendant's activities, the nature of the copyrighted work, the amount and substantiality of the use, and the effects of the use on the market for the copyrighted work. ${ }^{118}$ Accolade persuaded the court that decompilation was the only way Accolade could obtain access to the unprotectable interface information in Sega's game programs (apart from entering into an unacceptable licensing agreement) and that accessing and reusing this information had made it possible for Accolade to develop new non-infringing works to compete in the market with Sega's works. The court consequently decided that intermediate copying of programs for purpose of achieving interoperability was fair use. ${ }^{119}$ The court relied on economic reasoning in support of the ruling, although its analysis is not as systematically economic as some of the law review commentary reaching the same legal conclusion. ${ }^{120}$

Both Altai and Sega v. Accolade have been widely accepted as sound rules in the US and abroad, 121 and the software industry has continued to flourish in the decade after these decisions were rendered. ${ }^{122}$ While software law has now achieved a stability it lacked in the 1980s and early 1990s, challenges posed

113. See Sega Enterprises Ltd. v. Accolade, inc., 977 F.2d 1510 (9th Cir. 1992). [Sega] The Ninth Circuit had endorsed Whelan in Johnson Controls, Inc. v. Phoenix Control Systems, inc., 886 F.2d 1173 (9th Cir. 1989), but repudiated it in Sega at 1524-25.

114. See e.g. Andrew Johnson-Laird, "Software Reverse Engineering in The Real World" (1994) 19 U. Dayton L. Rev. 843.

115. 17 U.S.C. $\$ 106(1)(2001)<$ http:/frwebgate.access.gpo.gov/cgibinigetdoc.cgi?dloname=browse_usc\&docid=Cite:+17USC106>.

116. Although some software developers openly publish APIs (application programming interfaces) for their programs, many do not. The willingness of program developers to license APIs to other firms varies consider ably. Some firms only license APls on terms that some developers regard as unacceptable (e.g., giving up the right to make a version of the same program for other platformsl. See Sega, supra note 113 at 1514 .

117. 17 U.S.C. $\$ 107$ (2001) <http://frwebgate.access.gpo.gov/cgibin/getdoc.cgi?dbname=browse_usc\&docid=Cite:+17USC107?

118. The fair use defense is discussed in Sega, supra note 113 at 1520-28.

119. See e.g. Sega, supra note 113 at $1527-8$.

120. For scholarly commentary making economic arguments in favor of fair use for decompilation for purposes of interoperability, see e.g. Lawrence Graham \& Richard O. Zerbe, Jr., "Economically Efficient Treatment of Computer Software: Reverse Engineering, Protection and Disclosure" (1996) 22 Rutgers Computer \& Tech. L.J. 61 at 132-34; Lemley \& McGowan, supra nate 37, at 525; Samuelson \& Scotchmer, supra note 84, at $1621-26$.

121. See e.g. Band \& Katoh, supra note 112, at 271-82, 294-97; Jonathan Band, "Software Reverse Engineering Amendments in Singapore and Australia" (January 2000) J. Internet L. 17 at 20.

122. See e.g. PriceWaterhouse Coopers, Contributions of the Packaged Software industry to the Global Economy (1999), < http://global.bsa.org/usa/globallib/econ/pwc1999.pdf>. 
by new technologies for the application of copyright law to digital works continue to be troublesome. Perhaps the most potent example has been the entertainment industry lawsuits against the developers of peer to peer file sharing technologies. ${ }^{123}$ While economic analysis has been of some assistance to judges forced to grapple with the thorny legal issues these cases present, ${ }^{124}$ it may be necessary for legislatures to address what standards ought to apply in regulating technologies with infringing and non-infringing uses. ${ }^{125}$

It is worth noting that the Canadian Supreme Court recently considered another new technology issue that was certainly not anticipated when the Canadian legislature enacted its copyright law. The Court concluded that the economic rights of an artist were not infringed when a purchaser of copies of his work transferred the copyrighted image from paper to canvas and then resold the copies. ${ }^{126}$ Although not invoking economic analysis as such, the care with which the Canadian Court considered the economic impacts of the challenged use was impressive and bodes well for further uses of economic arguments in copyright cases in Canada.

\section{CONCLUSION}

COPYRIGHT IS AN IMPORTANT FORM of economic regulation. This essay has considered several reasons why economic analysis has had relatively little effect on copyright law and policy thus far. It has also argued that economics has much to offer in assisting policymakers and judges in crafting sound copyright law and policy.

There are several reasons why courts and policymakers may resist the incursion of economics into the copyright law and policymaking process and in the interpretation of copyright law. As noted in Section 2, many in the copyright field, including policymakers, have little or no economic expertise and little inclination to seek it out. Second, copyright industry professionals have been successful in getting much if not all of what they want without the aid of economics, so they may perceive little need for this analytical tool. Third, copyright industry professionals may be wary of embracing economics because although it may sometimes provide support for stronger protection rules, it may not always cut in their favor. They may resist embracing a tool that might provide grounds for

123. See e.g. Napster, supra note 40 (preliminary injunction against peer to peer software developer as a contributory and vicarious infringer of digitai music copyrights because of centralized directory and indexing functionality); in re Aimster Litigation, 334 F.3d 643 (7th Cir. 2003)

<http://www.ca7. uscourts.gov/op3.fwx?submit1 = showop\&caseno=02-4125.PDF> (summary judgment against peer to peer developer as contributory infringer because of direct assistance to infringements). But see Metro-Goldwyn-Mayer Studios, Inc. v. Grokster, Ltd., 259 F. Supp.2d 1029 (C.D. Cal. 2003). <http://wnm.cacd.uscourts.gov/CACD/RecentPubop.nsf/hb6 1c530eab0911<882567cfoo5ac6f9/882626055 381375988256 d5800654a59/\$FILE/CVO1-8541SWW.pdf> (summary judgment in favor of peer to peer software developer because of capability for substantiai noninfringing uses).

124. Supra note 41.

125. See e.g Metro-Goldwy-Mayer Studios, inc. v. Grokster, Ltd, supra note 123 (Brief Amicus Curiae of Forty intellectual Property Professors, <http://wmw.lawberkeley.edu/cenpro/samuelson/papers/briefs/ Grokster_Amicus_092603.pdf> (arguing that the legislature, not the courts, should regulate technologies with non-infringing uses).

126. See e.g. Theberge v. Galierie d'Art du Petit Champlain, inc, 2002 SCC 24, <http://www.lexum.unontreal.ca/csc-scc/en/pub/2002/vol2/html/2002scr2_0336.htmls, [2002] 2 S.C.R. 336 
policy outcomes they disfavor. Fourth, until some major participant in the copyright policy-making process decides that economic analysis would be valuable as input to the policy process, the inertia of the current situation is likely to persist.

Even so, I predict that economic analysis will have greater impact on copyright in the future. A new generation of scholars is building up a rich corpus of policy-relevant copyright research and is articulating the policy-relevant implications of this research. ${ }^{127}$ There is now a Society for Economic Research on Copyright Issues (SERCI), which hosts an annual international conference and publishes edited volumes of research on the economics of copyright. ${ }^{128}$ The increasing importance of copyright industries to the US and world economy should make policymakers more receptive to insights that economics can provide. ${ }^{129}$ Moreover, the inclusion of copyright and other intellectual property rights within the framework for promoting world trade by virtue of adoption of the TRIPS Agreement as part of the agreements establishing the World Trade Organization should lead to greater use of economic learning to shape global intellectual property norms. ${ }^{130}$ This should lead to greater reliance on economic expertise at the national legislative and policymaking process.

Perhaps it is only a matter of time before the U.S Copyright Office and sister agencies in other countries will hire not just a resident economist, but a group of them, one of which might be designated a Chief Economist, and give serious consideration to economic effects before endorsing particular legislative initiatives. Economic principles can contribute to evolving our understanding of the access/incentives tradeoff so that copyright will continue-or perhaps return to-its long-standing tradition of promoting the progress of science and the useful arts to the benefit of humankind.

127. See e.g. Yochai Benkler, "Intellectual Propenty and the Organization of Information Production" (2002) 22 Int'l Rev. of L. Econ. 81; Mark A. Lemley, "The Economics of improvement in intellectual Property Law" (1997) 75 Tex. L. Rev. 989; Glynn S. Lunney, Jr., "Reexamining Copyright's Incentives-Access Paradigm" (1996) 49 Vand. L. Rev. 483; Michael Meurer, "Copyright Law and Price Discrimination" (2001) 23 Cardozo L. Rev. 55; Christopher \$. Yoo, "Copyright and Product Differentiation" (2004) T9 N.Y.U. L. Rev. 212.

128. See e.g. Gordon \& Watt, supra note 10. For information about SERCl and its conferences, see <http://www.serci.org/>.

129. See e.g. Stephen E. Siwek \& Gale Mosteller, Copyright industries in the U.S. Economy: The 1998 Report (Washington, D.C.: International Intellectual Property Alliance, 1998),

<http://www.iipa.com/pdf/1998 SIWEK_EXEC.PDF> (exports of copyright-related products and services are increasing at an impressive rate-in 1996 their value surpassed that of every other export sector in the United States.)

130. See e.g. Pamela Samuelson, "Challenges for the World intellectual Property Organization and the TradeRelated Aspects of Intellectual Property Rights Council in Regulating Intellectual Property Rights in The Information Age" (1999) 21 Eur. I.P. Rev. 578. 
HeinOnline -- 1 U. Ottawa L. \& Tech. J. 22 2003-2004 